\title{
The Effect of Mixed Cultivation Using Companion Plants on the Growth and Quality of Cherry Tomatoes
}

\author{
Byoung-Kwon Lee ${ }^{1}$, Hyung Kwon Yun², In-Kyoung Hong ${ }^{3}$, Young-Bin Jung ${ }^{4}$, and Sang-Mi Lee ${ }^{4}$ \\ ${ }^{1}$ Research worker, Urban Agricultural Research Division, National Institute of Horticultural and Herbal Science, Rural Development \\ Administration, Wanju-gun, Jeolabuk-do 55365, Korea \\ ${ }^{2}$ Senior researcher, Urban Agricultural Research Division, National Institute of Horticultural and Herbal Science, Rural Development \\ Administration, Wanju-gun, Jeolabuk-do 55365, Korea \\ ${ }^{3}$ Postdoctoral researcher, Urban Agricultural Research Division, National Institute of Horticultural and Herbal Science, Rural Development \\ Administration, Wanju-gun, Jeolabuk-do 55365, Korea \\ ${ }^{4}$ Researcher, Urban Agricultural Research Division, National Institute of Horticultural and Herbal Science, Rural Development Administration, \\ Wanju-gun, Jeolabuk-do 55365, Korea
}

\section{ABSTRACT}

Background and objective: Recent urban agriculture meets the needs of urban residents that safety and avoids using chemical pesticides. This study was conducted to identify various factors of companion planting affecting the growth of cherry tomatoes, which will promoting urban agriculture by improving socioeconomic satisfaction with gardening activities through quality.

Methods: Four types of companion plants such as marigold, zinnia, spearmint and basil, that have a companion effect with growth, sugar content, and vitamin $\mathrm{C}$ content. We obtained the mean and standard deviation and tested the significance at a 95\% confidence level $(p<.05)$ with Duncan's multiple range test after one way ANOVA and MANOVA.

Results: Compared to monoculture of cherry tomatoes, the plant growth in the treatment plots with companion planting showed a significant increase overall( $p<.05)$, but there wasn't interaction effect among companion plants, planting ratio and type. As for the absorption of inorganic components, the companion planting showed better absorption than monoculture of cherry tomatoes, as favorable growth, and there was an interaction effect among the individual factors. The sugar content was higher than the standard sugar content of 5.8 brix in both the treatment plots at the control, and vitamin $\mathrm{C}$ content was higher than the control at $26.27 \mathrm{mg} / 100 \mathrm{~g}$ in all treatment plots, but there wasn't statistically significant difference. The soil pH in the cultivation plot ranges from 5.5 to 9.0 and was weakly alkaline in all treatment plots except zinnia, showing low contents of phosphoric acid, exchageable potassium, calcium and magnesium.

Conclusion: This study was conducted to analyze various factors such as the growth of cherry tomatoes, contents of inorganic components, sugar content and vitamin C content of fruits, and soil analysis according to companion plants, planting type, and planting ratio. We will study sugar content by measuring the change in growth every phase of fruits.

Keywords: environmentally friendly farming method, plant analysis, soil chemical properties, sugar content, urban agriculture

\section{Introduction}

Recent urban agriculture meets the needs of urban residents who want safe foods and prefer functional crops and avoids using chemical pesticides that contaminate the envi- ronment (soil, air, water quality, etc.), widely using mixed cultivation with companion plants as a sustainable, environmentally friendly farming method (Shin et al., 2014). Companion plants refer to plants that are planted together in gardening to help another plant or each other (Hong

\footnotetext{
This study is funded by the Rural Development Administration project (PJ015076012021).

Received: May 3, 2021, Revised: May 11, 2021, Accepted: June 25, 2021

First author: Byoung-Kwon Lee, lbg1114@korea.kr, (1) https://orcid.org/0000-0001-6842-9530

*Corresponding author: Hyung Kwon Yun, yun0309@korea.kr, (10) https://orcid.org/0000-0001-9973-4706
} 
et al., 2021). This planting method is related to environmentally friendly farming (Tringovska et al., 2015) and is a special mixed cultivation system that applies the effect of companion plants to soil environment and reduction of diseases and pests as well as damages from pathogens (Chang et al., 2017). Growing two or more plants together is generally a method to control diseases and pests in agricultural production, and it has various effects such as positively changing the surrounding microclimatic conditions, preserving water and nutrients by adding organic matter and nitrogen to soil, and suppressing weeds (Bomford, 2009; Gómez-Rodríguez et al., 2003), but it also reduces the yield of main crops due to interference such as competition over light, water, and nutrients (Borowy, 2012; Jedrszczyk and Poniedzialek, 2007; Lu et. al., 2000). Nonetheless, clusters and diversity of soil microbes play a significant role in the function and sustainability of the agricultural ecosystem (Shin et. al., 2014; Doran and Zeiss 2000), and the changed soil affects plant growth with plant-soil feedback (Bever, 1994; Putten et. al., 1993).

Cherry tomatoes (Lycopersicon esculentum) are comprised of $95 \%$ water, $0.7 \%$ protein, $0.1 \%$ fat, $3.3 \%$ carbohydrate, $0.4 \%$ cellulose, and $0.5 \%$ ash content (Chae, 2020), and are proved to have various functions such as antioxidant effect of lycopene or $\beta$-carotene and inhibition of oxidization by low density lipoprotein (LDL) (Lenucci et al., 2006). These days, the quantity of cherry tomatoes has somewhat increased with fertilization for high yield, but application of too much fertilizer is causing all kinds of physiological stress and environmental pollution problems due to salination of cultivation soil. Therefore, adequate fertilization methods are needed for plant growth, but there are insufficient standards and thus causing many difficulties in cultivation. Accordingly, based on understanding of growing conditions and crop physiology, it is necessary to establish a series of techniques suitable for soil and environment to increase sugar content, improve hardness, and control diseases and pests (RDA, 2005). This study selected 4 types of herbs and flowers such as basil (Ocimum basilicum), spearmint (Mentha spicata), marigold (Tagetes erecta L.), and garden zinnia (Zinnia elegans) with insecticidal, fumigating, and antibacterial effects proved by previous studies (Tringovska et al., 2015;
Moon, 2011) and determined the companion effect depending on planting type and planting ratio. Studies on environmentally friendly farming using companion plants examined the effect on cucumber growth (Chang et al., 2017), tomato growth (Liu et al., 2014; Held et al., 2003; Vernon et al., 2016; Tringovska et al., 2015), and weed suppression (Valentin et al., 2017), but very few examined the effect of companion plants on the growth of cherry tomatoes that are different from tomatoes. Accordingly, this study was conducted to identify various factors of companion planting affecting the growth of cherry tomatoes, which will contribute to promoting urban agriculture by improving socioeconomic satisfaction of urban residents with gardening activities through high yield, quality improvement, and adequate fertilization.

\section{Research Methods}

\section{Materials and methods}

To determine the effect of companion planting on the growth of cherry tomatoes as a method to promote garden diversity and find a sustainable plan to use urban gardens, this study created 76 rows with the width, length, and height of $1 \mathrm{~m}, 1 \mathrm{~m}$, and $0.3 \mathrm{~m}$ for 5 days from April 10, 2020 on the field of the National Institute of Horticultural and Herbal Science located in Iseo-myeon, Wanju-gun (Fig. 1A).

We selected the 'Minichal' variety of cherry tomatoes (Lycopersicon esculentum MILL.) that is most preferred by urban residents and selected marigold (Tagetes erecta L.), basil (Ocimum basilicum), spearmint (Mentha spicata), and garden zinnia (Zinnia elegans) that showed companion effects such as insecticidal, fumigating, and antibacterial effects proved by previous studies (Tringovska et. al., 2015., Moon, 2011) as companion plants. Cherry tomatoes were sowed and raised on gardening bed soil from January 10, 2020 and transplanted when the first flower of the first flower cluster bloomed on April 26, 2020. The plant spacing was $60 \mathrm{~cm}$, and we applied the two planting types, point type and round type, that showed the best growth effect in Chae et al. (2019) (Fig. 1B). The planting ratio of companion plants was $0 \%$ (9 main crops), $30 \%$ 


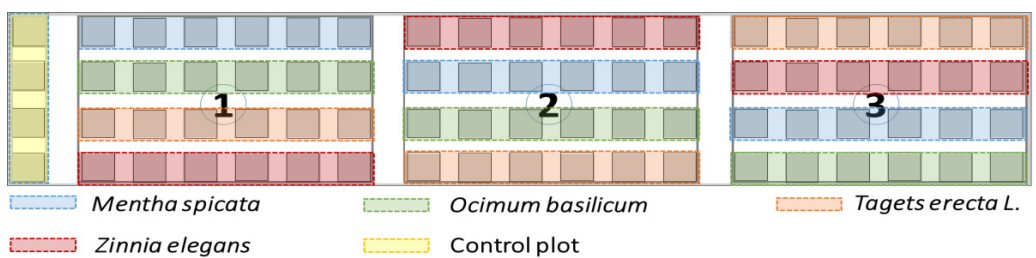

A. Field layout

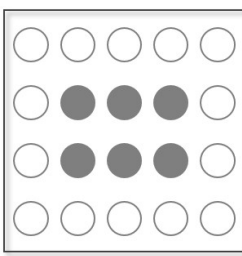

[ Point ]

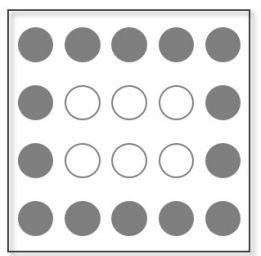

[Round ]
B. Planting type

Fig. 1. Experimental Layout(A) and planting type(B) on this study.

Table 1. Planting type and rate by field name on this study

\begin{tabular}{|c|c|c|c|c|c|c|c|}
\hline Treatment $^{x}$ & Companion plants & Type $^{y}$ & Ratio(\%) & Treatment $^{\mathrm{x}}$ & Companion plants & Type $^{y}$ & Ratio(\%) \\
\hline $\mathrm{Nt} 0$ & Non-treatment & - & 0 & $\mathrm{Nt} 0$ & Non-treatment & - & 0 \\
\hline MP3 & Mentha spicata & Point & 30 & MR3 & Mentha spicata & Round & 30 \\
\hline MP5 & & & 50 & MR5 & & & 50 \\
\hline MP7 & & & 70 & MR7 & & & 70 \\
\hline OP3 & Ocimum basilicum & Point & 30 & OR3 & Ocimum basilicum & Round & 30 \\
\hline OP5 & & & 50 & OR5 & & & 50 \\
\hline OP7 & & & 70 & OR7 & & & 70 \\
\hline TP3 & Tagetes erecta $\mathrm{L}$. & Point & 30 & TR3 & Tagetes erecta $L$. & Round & 30 \\
\hline TP5 & & & 50 & TR5 & & & 50 \\
\hline TP7 & & & 70 & TR7 & & & 70 \\
\hline $\mathrm{ZP} 3$ & Zinnia elegans & Point & 30 & ZR3 & Zinnia elegans & Round & 30 \\
\hline ZP5 & & & 50 & ZR5 & & & 50 \\
\hline ZP7 & & & 70 & ZR7 & & & 70 \\
\hline
\end{tabular}

${ }^{\mathrm{x}}$ Treatment is named after the $1^{\text {st }}$ letter of the companion plants name, planting type, and ratio

${ }^{\mathrm{y}}$ Type were planting method with point and round type.

${ }^{\mathrm{z}}$ Ratio means a percentage of planting for main crops and companion plants.

(6 main crops, 3 companion plants), 50\% (4 main crops, 5 companion plants), and 70\% (3 main crops, 6 companion plants), and the experiment was conducted in triplicate for each experimental plot (Table 1).

\section{Survey and analysis methods}

We analyzed the soil properties before transplant to determine the relationship between plant growth and absorption of inorganic components by soil in companion planting. Soil chemical properties followed the soil chemical analysis method by Rural Development Administration such as $\mathrm{pH}$, organic content, available $\mathrm{P}_{2} \mathrm{O}_{5}$ and $\mathrm{K}, \mathrm{Na}, \mathrm{Ca}, \mathrm{Mg}$, etc. As a result, $\mathrm{pH}$ was 7.09 , phosphoric acid content $72.49 \mathrm{mg} / \mathrm{kg}$, exchangeable potassium $0.24 \mathrm{cmol}+/ \mathrm{kg}$, and exchangeable calcium $4.53 \mathrm{cmol}+/ \mathrm{kg}$ (Table 2), which were generally low compared to the recommended standard for cherry tomatoes. Thus, additional fertilization was done 3 times (nitrogen $11.3 \mathrm{~kg} /$ potassium $8.3 \mathrm{~kg}$ per 10a). Soil samples were collected again 70 days after transplant to determine the change in absorption of inorganic nutrients from soil before and after planting.

Starting with the initial investigation on April 28, 2020, we investigated length, stem thickness, total fruit quantity, weight, and hardness on July 17. The growth and quantity of crops were surveyed based on the standards of experimental agriculture by Rural Development Administration (RDA, 2012).

Sugar content was measured with a refractometer (ATAFGO PAL-1) by collecting samples and extracting juice from 
Table 2. Characteristic of soil on cultivation plot before experiment

\begin{tabular}{ccccccccccc}
\hline \multirow{2}{*}{ Division $^{\mathrm{x}}$} & $\mathrm{pH}$ & $\mathrm{EC}$ & avaliable $\mathrm{P}_{2} \mathrm{O}_{5}$ & \multicolumn{3}{c}{ Exchangeable. Cation $(\mathrm{cmol}+/ \mathrm{kg})$} & \multicolumn{2}{c}{$\mathrm{NH}_{4}-\mathrm{N}$} & $\mathrm{NO}_{3}-\mathrm{N}$ \\
\cline { 2 - 11 } & $(1: 5)$ & $(\mathrm{dS} / \mathrm{m})$ & $(\mathrm{mg} / \mathrm{kg})$ & $\mathrm{K}$ & $\mathrm{Ca}$ & $\mathrm{Mg}$ & $\mathrm{Na}$ & $(\mathrm{mg} / \mathrm{kg})$ & $(\mathrm{mg} / \mathrm{kg})$ \\
\hline $\mathrm{CP} 1$ & 7.85 & 0.28 & 71.07 & 0.25 & 4.27 & 2.57 & 0.06 & $21.61 \pm 1.94$ & $6.74 \pm 1.23$ \\
$\mathrm{CP} 2$ & 6.73 & 0.33 & 75.12 & 0.19 & 4.36 & 2.61 & 0.06 & $27.53 \pm 0.65$ & $0 \pm 0$ \\
$\mathrm{CP} 3$ & 6.7 & 0.48 & 71.28 & 0.28 & 4.93 & 2.83 & 0.07 & $26.27 \pm 0.48$ & $0 \pm 0$ \\
$\mathrm{SD}^{\mathrm{y}}$ & $7.09 \pm 0.66$ & $0.36 \pm 0.10$ & $72.49 \pm 2.28$ & $0.24 \pm 0.04$ & $4.52 \pm 0.36$ & $2.67 \pm 0.14$ & $0.06 \pm 0.00$ & $27.39 \pm 1.06$ & $0.16 \pm 0.27$ \\
\hline
\end{tabular}

${ }^{\mathrm{x}}$ Division was based on the abbreviation for cultivation plot and the number of iterations.

${ }^{\mathrm{y}}$ Standard division

\begin{tabular}{|ll|}
\hline $\mathrm{S} \times(\mathrm{a} \times \mathrm{b}) /$ sample $(\mathrm{g}) \times 100 / 1000$ & $\mathrm{~S}:$ Ascorbic acid concentration in test $(\mu \mathrm{g} / \mathrm{ml})$ \\
& $\mathrm{a}:$ Total amount of test solution $(\mathrm{ml})$ \\
& $\mathrm{b}:$ Dilution factor of test solution \\
\hline
\end{tabular}

Fig. 2. Formula to find vitamin $\mathrm{C}$ content.

them, after which we marked the sugar content in ${ }^{\circ}$ Brix up to one decimal place. Vitamin $\mathrm{C}$ content was analyzed using high-performance liquid chromatography (Agilent Technologies 1260 Infinity II ). This was performed according to the research and analysis criteria of the Ministry of Food and Drug Safety (MFDS, 2000), and the result is obtained as shown in Fig. 2.

Samples for plant body analysis were harvested and separated into stems, leaves, and roots in each experimental plot. Then they were washed with water, dried at $70^{\circ} \mathrm{C}$, and pulverized to 100 mesh on a grinder. We obtained samples with nitric acid $\left(\mathrm{HNO}_{3}\right)$ and perchloric acid wet digestion method through preprocessing of the plant body, after which we used ICP (Integra XM2, GBC Scientific Equipment, Australia) to analyze the plant body using the soil chemical analysis method (NIAST, 2000). The results were analyzed with IBM SPSS statistics Ver. 25 program to obtain the mean and standard deviation. To verify the difference in variables, we surveyed the correlation among dependent variables and conducted multivariate analysis of variance (MANOVA) for growth and one-way ANOVA for vitamin $\mathrm{C}$ content. Then we conducted multivariate testing of each individual factor of companion plants, planting type, and planting ratio and tested the significance at a $95 \%$ confidence level $(p<.05)$ using Duncan's multiple range test.

\section{Results and Discussion}

\section{Growth of cherry tomatoes and changes in the contents of inorganic components}

\section{Growth of cherry tomatoes}

Compared to monoculture of cherry tomatoes, the growth of plant bodies in the experimental plots with companion planting showed a significant increase overall $(p<.05)$. Length was MP7 $187.3 \mathrm{~cm}>$ OR5 $184.3 \mathrm{~cm}>$ TP7 183.7 $\mathrm{cm}>$ TR5 $182.0 \mathrm{~cm}>$ TR7 $181.3 \mathrm{~cm}$, showing the greatest effect when planning companion plant 'mint' in the point type (70\% ratio). Basil and marigold were also long at the ratio of $50 \%$ and $70 \%$. Stem thickness was TP7 $12.4 \mathrm{~mm}$ $>$ MP7 $11.7 \mathrm{~mm}>$ ZP3 \& ZP5 $11.6 \mathrm{~mm}>$ OR5 \& ZR5 $11.3 \mathrm{~mm}$, which was $1.6-2.7 \mathrm{~mm}$ thicker than the control plot $(9.7 \mathrm{~mm})$. Total fruit yield was MP7 97 pieces $>$ TP7 91 pieces $>$ TR7 \& ZP7 \& ZP5 88 pieces, harvesting 32-35 more than 56 in the control plot. Total weight of harvested fruits was MP7 $1262.6 \mathrm{~g}>$ TP7 $1226.6 \mathrm{~g}>$ ZP5 $1209.8 \mathrm{~g}$ $>$ ZP7 $1196.2 \mathrm{~g}>$ TR7 1118.1 g, showing 108.5-645.6 g more weight than the control plot at $617.0 \mathrm{~g}$. All experimental plots showed better growth than the control plot, and the weight of each fruit in the experimental plot was MR5 13.83g > MP5 $13.60 \mathrm{~g}>$ ZR7 $13.52 \mathrm{~g}>$ MP7 $13.02 \mathrm{~g}$ $>$ ZP5 $13.00 \mathrm{~g}$, which was within the range of 10.69-13.83 g. Fruit hardness was highest in MP7 and Nt0 control plot 
at $2.7 \mathrm{~kg}$ and lowest in TR3 $(1.8 \mathrm{~kg})$, showing that all experimental plots were better than pieces (Table 3).

Compared to monoculture of cherry tomatoes, cherry tomatoes cultivated with companion plants such as mint, basil, marigold, and garden zinnia showed significantly better growth. However, as a result of analyzing the difference in individual growth between monoculture of cherry tomatoes and companion planting using Wilks' statistics, lambda value was $0.922, \mathrm{~F}$-value was 1.362 , and p-value was 0.143 , and thus there was no significant difference in growth of monoculture and companion planting at $p>.05$. As a result of the posttest, there was a difference between the control plot and experimental plots except for fruit hardness (Table 4). This result is consistent with the study by Tringovska et al., (2015) reporting that companion planting does not affect growth but helps inhibit root-knot nematodes in soil.

By planting type, cherry tomatoes showed better growth overall in the experimental plots with mixed cultivation by planting type than the control plot growing only cherry tomatoes, except for fruit hardness. Wilks' statistics of MANOVA of the control plot growing only cherry tomatoes and the experimental plots with mixed cultivation of companion plants in the point type and round type showed

Table 3. Growth result of cherry tomatoes.

\begin{tabular}{|c|c|c|c|c|c|c|}
\hline \multirow{2}{*}{ Treatment $^{\mathrm{y}}$} & \multirow{2}{*}{$\begin{array}{c}\text { Plant length } \\
\mathrm{cm}\end{array}$} & \multirow{2}{*}{$\begin{array}{c}\text { Stem thickness } \\
\mathrm{mm}\end{array}$} & \multirow{2}{*}{$\begin{array}{c}\text { Total quantity } \\
\text { ea treatment }\end{array}$} & \multicolumn{2}{|c|}{ Weight } & \multirow{2}{*}{$\begin{array}{c}\text { Fruit hardnes } \\
\mathrm{kg} / \mathrm{cm}^{2}\end{array}$} \\
\hline & & & & $\mathrm{g} /$ Total & g/ea & \\
\hline $\mathrm{Nt0}$ & $162.6 \pm 19.7$ & $9.7 \pm 1.8$ & $56.3 \pm 13.9$ & $617.0 \pm 206.4$ & $10.7 \pm 1.5$ & $2.7 \pm 0.3$ \\
\hline MR3 & $170.8 \pm 19.2$ & $10.8 \pm 1.3$ & $71.7 \pm 18.0$ & $896.0 \pm 266.0$ & $11.5 \pm 2.2$ & $2.6 \pm 0.4$ \\
\hline MR5 & $178.8 \pm 30.5$ & $11.6 \pm 1.4$ & $87.5 \pm 14.8$ & $1209.8 \pm 308.6$ & $11.8 \pm 2.2$ & $2.5 \pm 0.3$ \\
\hline MR7 & $178.2 \pm 16.5$ & $11.2 \pm 1.8$ & $88.0 \pm 13.6$ & $1196.2 \pm 201.4$ & $11.8 \pm 3.1$ & $2.5 \pm 0.4$ \\
\hline MP3 & $162.5 \pm 24.2$ & $10.8 \pm 1.4$ & $67.9 \pm 15.9$ & $725.5 \pm 272.0$ & $10.6 \pm 2.7$ & $2.6 \pm 0.2$ \\
\hline MP5 & $172.2 \pm 25.4$ & $10.4 \pm 1.2$ & $78.5 \pm 23.1$ & $1067.5 \pm 261.0$ & $11.8 \pm 4.2$ & $2.6 \pm 0.4$ \\
\hline MP7 & $187.3 \pm 7.4$ & $11.7 \pm 1.5$ & $97.0 \pm 19.6$ & $1262.6 \pm 480.8$ & $12.9 \pm 3.7$ & $2.7 \pm 0.2$ \\
\hline OR3 & $166.8 \pm 10.2$ & $11.2 \pm 1.4$ & $67.1 \pm 17.7$ & $766.0 \pm 285.7$ & $12.4 \pm 2.9$ & $2.2 \pm 0.7$ \\
\hline OR5 & $175.3 \pm 8.9$ & $11.2 \pm 1.8$ & $69.0 \pm 22.6$ & $841.3 \pm 336.2$ & $12.7 \pm 1.7$ & $2.2 \pm 0.8$ \\
\hline OR7 & $171.4 \pm 32.4$ & $11.3 \pm 2.2$ & $73.9 \pm 27.7$ & $925.5 \pm 393.9$ & $12.3 \pm 2.6$ & $2.5 \pm 0.4$ \\
\hline OP3 & $171.2 \pm 20.6$ & $10.1 \pm 2.0$ & $70.3 \pm 19.2$ & $820.1 \pm 347.9$ & $10.7 \pm 4.6$ & $2.6 \pm 0.2$ \\
\hline OP5 & $178.9 \pm 13.1$ & $10.3 \pm 2.0$ & $81.8 \pm 14.3$ & $992.7 \pm 316.8$ & $11.9 \pm 4.2$ & $2.6 \pm 0.2$ \\
\hline OP7 & $164.8 \pm 35.7$ & $10.3 \pm 1.5$ & $71.9 \pm 25.0$ & $915.3 \pm 420.0$ & $12.6 \pm 1.5$ & $2.4 \pm 0.2$ \\
\hline TR3 & $162.8 \pm 26.9$ & $10.4 \pm 1.3$ & $71.4 \pm 21.3$ & $864.7 \pm 314.2$ & $11.3 \pm 3.4$ & $1.8 \pm 1.3$ \\
\hline TR5 & $182.0 \pm 10.7$ & $10.6 \pm 1.4$ & $83.7 \pm 18.6$ & $1048.3 \pm 239.1$ & $12.7 \pm 2.7$ & $2.3 \pm 0.8$ \\
\hline TR7 & $181.3 \pm 13.8$ & $11.1 \pm 0.6$ & $88.3 \pm 22.6$ & $1118.1 \pm 404.1$ & $12.4 \pm 1.9$ & $2.5 \pm 0.1$ \\
\hline TP3 & $182.9 \pm 13.2$ & $10.4 \pm 1.3$ & $84.5 \pm 18.9$ & $1076.2 \pm 422.7$ & $11.0 \pm 1.5$ & $2.5 \pm 0.2$ \\
\hline TP5 & $184.9 \pm 15.7$ & $10.6 \pm 1.8$ & $82.9 \pm 16.1$ & $1056.9 \pm 275.4$ & $12.0 \pm 2.6$ & $2.4 \pm 0.8$ \\
\hline TP7 & $172.7 \pm 27.5$ & $10.9 \pm 1.3$ & $77.0 \pm 24.9$ & $959.1 \pm 406.3$ & $12.9 \pm 2.8$ & $2.5 \pm 0.2$ \\
\hline ZR3 & $169.5 \pm 10.3$ & $10.5 \pm 1.1$ & $71.7 \pm 10.6$ & $799.6 \pm 193.1$ & $10.5 \pm 3.4$ & $2.6 \pm 0.2$ \\
\hline ZR5 & $163.7 \pm 36.0$ & $10.7 \pm 0.9$ & $70.7 \pm 25.8$ & $881.3 \pm 453.8$ & $10.9 \pm 3.9$ & $2.6 \pm 0.3$ \\
\hline ZR7 & $183.7 \pm 36.6$ & $12.4 \pm 2.7$ & $90.7 \pm 29.6$ & $1226.6 \pm 594.0$ & $11.0 \pm 4.2$ & $2.6 \pm 0.3$ \\
\hline $\mathrm{ZP} 3$ & $169.8 \pm 9.1$ & $10.3 \pm 1.0$ & $68.2 \pm 15.2$ & $836.4 \pm 278.9$ & $12.3 \pm 1.6$ & $2.4 \pm 0.9$ \\
\hline ZP5 & $154.3 \pm 32.8$ & $9.9 \pm 1.8$ & $66.8 \pm 26.4$ & $868.0 \pm 395.4$ & $13.7 \pm 1.9$ & $2.6 \pm 0.2$ \\
\hline ZP7 & $175.3 \pm 23.3$ & $10.5 \pm 1.3$ & $80.3 \pm 15.4$ & $1003.7 \pm 250.9$ & $13.7 \pm 2.1$ & $2.6 \pm 0.3$ \\
\hline Significant & $.007 * *$ & $.006^{* *}$ & $.000 * * *$ & $.000 * * *$ & $.118^{\mathrm{NS}}$ & $.000 * * *$ \\
\hline
\end{tabular}

${ }^{\mathrm{y}}$ Treatment were derived from Table 1 .

NS, ${ }^{* *}, * * *$ Non-significant, $p<.01,<.001$ by ANOVA test 
the following results. Lambda value was 0.944 , F-value was 2.957 , and p-value was 0.008 , showing a statistically significant difference. Thus, mixed cultivation by planting type seems more effective in growth than monoculture of cherry tomatoes, and the posttest results showed that all items of growth except fruit hardness were different from the control plot (Table 5).

By planting ratio of companion plants, cherry tomatoes showed better growth overall in the experimental plots with mixed cultivation by planting type than the control plot growing only cherry tomatoes, except for fruit hardness, showing effect in the order of $70 \%>50 \%>30 \%$ (Table 6). Wilks' statistics of MANOVA were as follows. Lambda value was 0.884 , F-value was 3.146 , and p-value was $p<.000$, showing a statistically significant difference. Thus, mixed cultivation of companion plants by planting

Table 4. Growth result of cherry tomatoes by companion plants.

\begin{tabular}{|c|c|c|c|c|c|c|c|}
\hline \multirow{2}{*}{ Crops } & \multirow{2}{*}{$\begin{array}{c}\text { Growth } \\
\text { Unit } \\
\end{array}$} & \multirow{2}{*}{$\begin{array}{c}\text { Plant length } \\
\mathrm{cm} \\
\end{array}$} & \multirow{2}{*}{$\begin{array}{c}\text { stem thickness } \\
\mathrm{mm}\end{array}$} & \multirow{2}{*}{$\frac{\text { total quantity }}{\text { piece }}$} & \multicolumn{2}{|c|}{ weight } & \multirow{2}{*}{$\begin{array}{c}\text { Fruithardness } \\
\mathrm{kg} / \mathrm{cm}^{2}\end{array}$} \\
\hline & & & & & $\mathrm{g} /$ Total & g/ea & \\
\hline Control & Non-treatment & $162.6 \pm 19.7 \mathrm{a}$ & $9.7 \pm 1.8 \mathrm{a}$ & $56 \pm 14 \mathrm{a}$ & $617 \pm 206.4 \mathrm{a}$ & $10.8 \pm 1.4 \mathrm{a}$ & $2.7 \pm 0.3 \mathrm{c}$ \\
\hline \multirow{4}{*}{ Experimental } & Mint & $171.7 \pm 23.3 b$ & $10.6 \pm 1.6 b$ & $76 \pm 21 b$ & $929.1 \pm 372.6 b$ & $12.1 \pm 4.0 \mathrm{~b}$ & $2.6 \pm 0.3 b c$ \\
\hline & Basil & $173.4 \pm 22.2 b$ & $10.40 \pm 1.38 \mathrm{~b}$ & $76 \pm 20 b$ & $959.5 \pm 347.0 \mathrm{~b}$ & $12.4 \pm 2.3 \mathrm{~b}$ & $2.5 \pm 0.6 \mathrm{ab}$ \\
\hline & Marigold & $172.4 \pm 24.7 b$ & $10.84 \pm 1.49 b c$ & $78 \pm 22 b$ & $954.9 \pm 379.7 b$ & $12.0 \pm 2.1 \mathrm{~b}$ & $2.4 \pm 0.8 \mathrm{a}$ \\
\hline & Zinnia & $173.0 \pm 20.4 b$ & $11.16 \pm 1.57 \mathrm{c}$ & $75 \pm 20 b$ & $951.0 \pm 334.2 \mathrm{~b}$ & $12.4 \pm 1.9 \mathrm{~b}$ & $2.4 \pm 0.5 \mathrm{ab}$ \\
\hline \multicolumn{2}{|c|}{$\mathrm{F}$} & \multicolumn{6}{|c|}{1.362} \\
\hline \multicolumn{2}{|c|}{ Significant } & \multicolumn{6}{|c|}{$.143^{\mathrm{NS}}$} \\
\hline
\end{tabular}

${ }^{\mathrm{NS}}$ Non-significant by MANOVA test.

Table 5. Growth result of cherry tomatoes by type of planting

\begin{tabular}{|c|c|c|c|c|c|c|c|}
\hline \multirow{2}{*}{ Planting type } & \multirow{2}{*}{$\begin{array}{c}\text { Growth } \\
\text { Unit }\end{array}$} & \multirow{2}{*}{$\begin{array}{c}\text { Plant length } \\
\mathrm{cm}\end{array}$} & \multirow{2}{*}{$\begin{array}{c}\text { stem thickness } \\
\mathrm{mm}\end{array}$} & \multirow{2}{*}{$\begin{array}{c}\text { total quantity } \\
\text { piece }\end{array}$} & \multicolumn{2}{|c|}{ weight } & \multirow{2}{*}{$\begin{array}{c}\text { Fruithardness } \\
\mathrm{kg} / \mathrm{cm}^{2}\end{array}$} \\
\hline & & & & & $\mathrm{g} /$ Total & $\mathrm{g} / \mathrm{ea}$ & \\
\hline Control & Non-treatment & $162.6 \pm 19.7 \mathrm{a}^{\mathrm{z}}$ & $9.7 \pm 1.8 \mathrm{a}$ & $56.0 \pm 14.0 \mathrm{a}$ & $617.0 \pm 206.4 \mathrm{a}$ & $10.8 \pm 1.4 \mathrm{a}$ & $2.7 \pm 0.3 \mathrm{~b}$ \\
\hline \multirow{2}{*}{ Experimental } & Point & $170.8 \pm 24.3 \mathrm{~b}$ & $10.8 \pm 1.5 \mathrm{~b}$ & $76.0 \pm 21.0 \mathrm{~b}$ & $955.6 \pm 365.2 b$ & $12.4 \pm 3.1 \mathrm{~b}$ & $2.6 \pm 0.4 \mathrm{~b}$ \\
\hline & Round & $174.5 \pm 20.5 b$ & $10.7 \pm 1.6 \mathrm{~b}$ & $77.0 \pm 21.0 \mathrm{~b}$ & $941.2 \pm 349.6 \mathrm{~b}$ & $12.0 \pm 2.2 \mathrm{~b}$ & $2.4 \pm 0.7 \mathrm{a}$ \\
\hline \multicolumn{2}{|c|}{$\mathrm{F}$} & \multicolumn{6}{|c|}{2.957} \\
\hline \multicolumn{2}{|c|}{ Significant } & \multicolumn{6}{|c|}{$.008^{* *}$} \\
\hline
\end{tabular}

${ }^{\mathrm{z}}$ It means for groups in homogeneous subsets as result of post-validation.

${ }^{* *} p<.01$ by MANOVA test.

Table 6. Growth result of cherry tomatoes by planting ratio.

\begin{tabular}{|c|c|c|c|c|c|c|c|}
\hline \multirow{2}{*}{ Planting ratio } & \multirow{2}{*}{$\frac{\text { Growth }}{\text { Unit }}$} & \multirow{2}{*}{$\begin{array}{c}\text { Plant length } \\
\mathrm{cm}\end{array}$} & \multirow{2}{*}{$\begin{array}{c}\text { stem thickness } \\
\mathrm{mm}\end{array}$} & \multirow{2}{*}{$\begin{array}{c}\text { total quantity } \\
\text { piece }\end{array}$} & \multicolumn{2}{|c|}{ weight } & \multirow{2}{*}{$\frac{\text { Fruithardness }}{\mathrm{kg} / \mathrm{cm}^{2}}$} \\
\hline & & & & & $\mathrm{g} /$ Total & g/ea & \\
\hline Control & $0 \%$ & $162.6 \pm 19.7 \mathrm{a}^{\mathrm{z}}$ & $9.7 \pm 1.8 \mathrm{a}$ & $56.0 \pm 14.0 \mathrm{a}$ & $617.0 \pm 206.4 \mathrm{a}$ & $10.8 \pm 1.4 \mathrm{a}$ & $2.7 \pm 0.3 b$ \\
\hline \multirow{3}{*}{ Experimental } & $30 \%$ & $169.4 \pm 18.3 \mathrm{ab}$ & $10.6 \pm 1.4 \mathrm{~b}$ & $71.0 \pm 17.0 \mathrm{~b}$ & $845.0 \pm 307.5 b$ & $11.6 \pm 2.2 \mathrm{a}$ & $2.4 \pm 0.7 \mathrm{a}$ \\
\hline & $50 \%$ & $173.8 \pm 24.9 \mathrm{~b}$ & $10.7 \pm 1.6 \mathrm{bc}$ & $78.0 \pm 21.0 \mathrm{bc}$ & $995.7 \pm 339.1 \mathrm{c}$ & $12.8 \pm 3.3 b$ & $2.5 \pm 0.5 \mathrm{a}$ \\
\hline & $70 \%$ & $176.8 \pm 25.8 b$ & $11.2 \pm 1.8 \mathrm{c}$ & $83.0 \pm 23.0 \mathrm{c}$ & $1075.9 \pm 411.9 \mathrm{c}$ & $12.6 \pm 2.4 \mathrm{~b}$ & $2.5 \pm 0.3 \mathrm{ab}$ \\
\hline \multicolumn{2}{|l|}{$\mathrm{F}$} & \multicolumn{6}{|c|}{3.146} \\
\hline \multicolumn{2}{|c|}{ Significant } & \multicolumn{6}{|c|}{$.000^{* * * *}$} \\
\hline
\end{tabular}

${ }^{\mathrm{z}}$ It means for groups in homogeneous subsets as result of post-validation.

${ }^{* * *} p<.001$ by MANOVAt est. 
ratio was more effective in growth than monoculture of cherry tomatoes. The posttest results showed that length and weight per fruit were similar with the control plot at the ratio of $30 \%$, and different at the ratio of $50 \%$ and $70 \%$. Stem thickness, total quantity, and total weight all showed a difference in the experimental plots compared to the control plot.

To test the effect among individual factors, we examined the F-distribution of Wilks' lambda and found that companion plants and planting type were statistically significant $(p<.01)$, and there was no significant difference between companion plants and planting ratio $(p>.05)$, but a difference in growth between planting type and planting ratio $(p<.01)$. As a result of testing the effect among three individuals, Sig. of $\mathrm{F}=0.943>0.05$, and thus there was no interaction effect among companion plants, planting ratio, and planting type (Table 7).

\section{Inorganic components of the plant body}

The results of harvesting the aerial parts of cherry tomatoes 70 days after sowing and analyzing the mineral content were statistically significant (Table 8 ). Nitrogen $(\mathrm{N})$ was mostly distributed in leaves as a constituent of chlorophyll, protein, and enzyme, and it was redistributed well in the order of roots $>$ stems, showing high content in both leaves and roots compared to standard content $8.1 \mathrm{mg}$ (RDA, 2005). Compared to the control plot, roots were all high or showed a significant difference except ZR3 and leaves except MR3, MR5, OP5, OP7, TR7, TP3, ZR5. This result was similar to the study by Lee (2005) claiming that the absorption amount was biggest between 60 and 90 days after transplant. Potassium (K) involved in photosynthesis and carbohydrate synthesis is mostly distributed in leaves with active photosynthesis, followed by stems $>$ roots, which was generally higher than the control plot but all lower than standard content $16.4 \mathrm{mg}$ except leaves. This result was similar to the study by Papadopopoulos (1986), which proved that nitrogen and potassium are in competition over nutrient uptake of plants, and an increase in nitrogen concentration in soil leads to an increase in nitrogen content in plants, but a decrease in potassium content. Phosphorus (P) is adjusted by $\mathrm{pH}$ in soil, and it is distributed mostly in stems and leaves during vegetative growth and not much in roots.

According to Moon and Yoo (2013), the absorbed phosphorus is distributed inside the body in the form of organic phosphorus compound or inorganic phosphate and involved in cell growth and proliferation, and thus requires separate management with basal or root fertilization for fruit growth. Calcium (Ca), which is distributed mainly in soil and has low plant absorption rate, is distributed mostly in leaves, followed by stems $>$ roots. The calcium absorption amount of the plant body was greater than soil, showing a difference from conventional culture in which calcium is distributed in soil. Magnesium $(\mathrm{Mg})$ is a component with severe antagonism with other cations and is mostly distributed in leaves with chlorophyll, followed by roots $>$ stems. This content is far beneath the adequate threshold (4.76 mg/ $\mathrm{kg}^{-1}$ ) by excessive absorption of potassium. However, phosphoric acid, calcium, and magnesium tended to increase along with the amount of applied fertilizer. As reported by Hanan (1998) and Lindsay (1979), mineral content in some plant bodies decreased when soil $\mathrm{pH}$ increased because there was antagonism among cations in the absorption process by increasing the amount of solubilized calcium and magnesium in soil, which was also reported similarly by Mengel and Kirkby (1987) and Marschner (1995). All mineral elements showed a statistical difference at

Table 7. Mutual relation of individual factors on this study.

\begin{tabular}{cccc}
\hline Factor & Statistical Value & F & Significant \\
\hline Companion plant * Planting type & 0.890 & 1.972 & $.009^{* *}$ \\
Companion plant * Planting ratio & 0.898 & 0.896 & $.646^{\mathrm{NS}}$ \\
Planting type * Planting ratio & 0.930 & 1.826 & $.041^{*}$ \\
Companion plant * Planting type * Planting ratio & 0.894 & 0.943 & $.566^{\mathrm{NS}}$ \\
\hline
\end{tabular}

NS, *, * Non-significant $p<.05, .01$ by MANOVA test. 


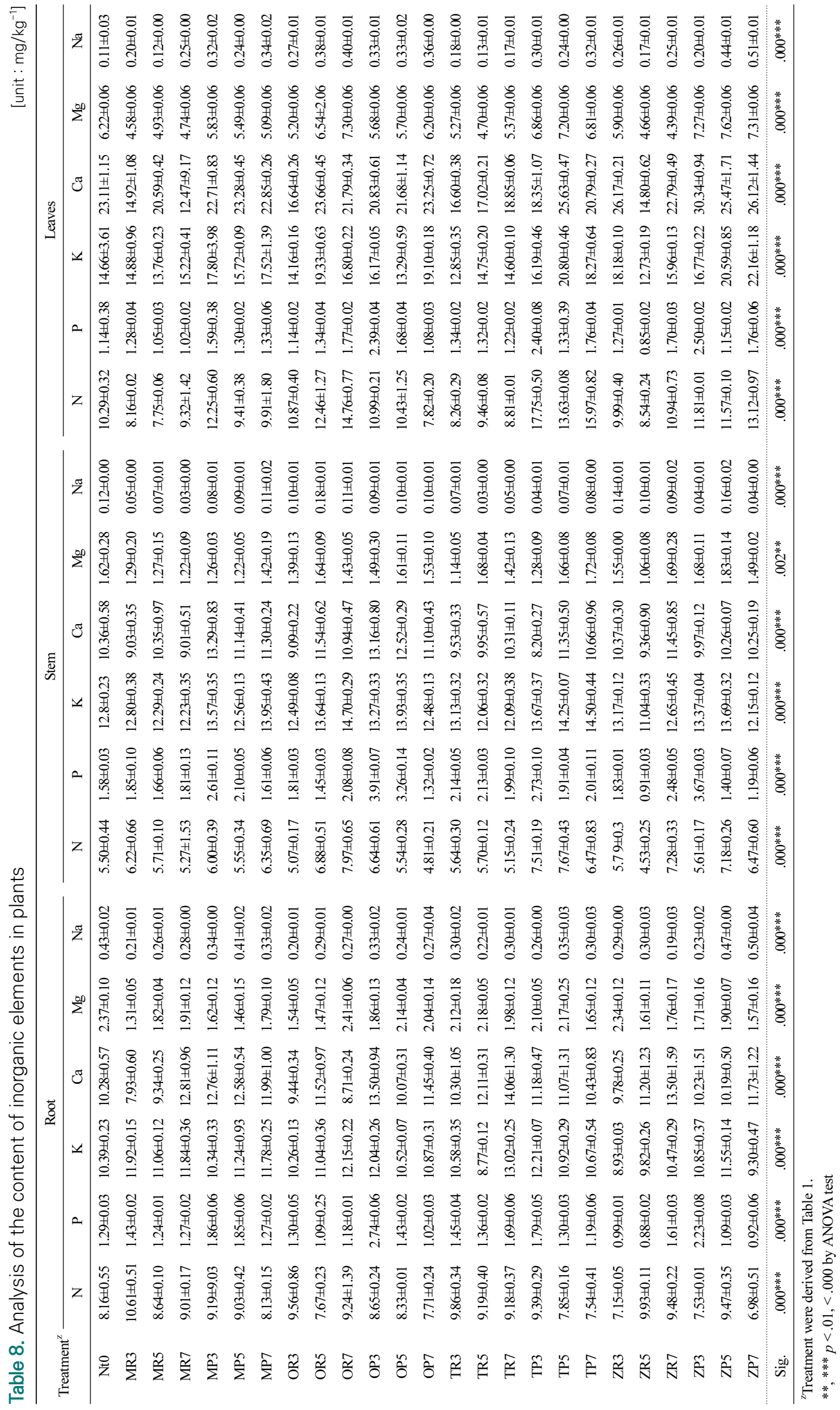


$0.1 \%$. Sodium $(\mathrm{Na})$, which is not an essential element but a beneficial element, is involved in increasing quantity and mostly distributed in roots, followed by leaves $>$ stems, and will have effect as a substitute of potassium.

Compared to the control plot with monoculture of just cherry tomatoes, the contents of inorganic components in cherry tomatoes cultivated with companion plants such as mint, basil, marigold, and garden zinnia was significantly higher in most cases except magnesium and sodium in roots and stems, and calcium and magnesium in leaves (Table 9). As for the difference in inorganic components among individuals between monoculture of cherry tomatoes and companion planting, Wilks' lambda was 0.000, F-value was 72.111, and p-value was $p<.001$, showing a statistically significant difference, proving that mixed cultivation of companion plants showed more difference in the contents of inorganic components than monoculture of cherry tomatoes. The posttest results showed that roots showed a difference from the control plot in most components except nitrogen and calcium, and stems and leaves showed a difference from the control plot in most components except calcium and magnesium. This result was consistent with the investigation of plant body growth and similar to the study by Chang et al. (2017) stating that inorganic components affect crop growth.

By planting type, roots and stems showed low content of magnesium and sodium in both the point type and round type, while leaves had low content of calcium and magnesium in the round type, but the contents of inorganic components was generally higher in the experimental plots compared to the control plot (Table 10). As a result of multivariate testing, Wilks' lambda was .010, F-value was 178.947 , and p-value was .000 , showing a statistically significant difference, proving that planting type determines the effect of absorption of inorganic components within the plant body of cherry tomatoes. The posttest results showed that roots showed a difference from the control plot in most components, but nitrogen showed a difference in the point type and phosphorus in the round type, while calcium showed a similar content between the point type and round type. Stems showed a difference in most components in the point type except nitrogen and calcium, whereas only phosphorus and sodium showed a difference in the round type. Leaves showed a difference in most components except calcium and magnesium, whereas only calcium and sodium showed a difference in the round type.

Table 9. Analysis of the content of inorganic elements in plants by companion plants.

[Unit: $\mathrm{mg} / \mathrm{kg}^{-1}$ ]

\begin{tabular}{|c|c|c|c|c|c|c|c|c|c|c|c|c|c|c|c|c|c|c|c|}
\hline \multirow{2}{*}{ Plant } & \multirow{2}{*}{$\frac{\text { Part }}{\text { Component }}$} & \multicolumn{6}{|c|}{ Root } & \multicolumn{6}{|c|}{ Stem } & \multicolumn{6}{|c|}{ Leaves } \\
\hline & & $\mathrm{N}$ & $\mathrm{P}$ & $\mathrm{K}$ & $\mathrm{Ca}$ & $\mathrm{Mg}$ & $\mathrm{Na}$ & $\mathrm{N}$ & $P$ & K & $\mathrm{Ca}$ & $\mathrm{Mg}$ & $\mathrm{Na}$ & $\mathrm{N}$ & $\mathrm{P}$ & K & $\mathrm{Ca}$ & $\mathrm{Mg}$ & $\mathrm{Na}$ \\
\hline \multirow{4}{*}{ Control } & \multirow{4}{*}{ Non-treatment } & 8.16 & 1.29 & 10.39 & 10.28 & 2.37 & 0.43 & 5.50 & 1.58 & 12.85 & 10.36 & 1.62 & 0.12 & 10.29 & 1.14 & 14.66 & 23.11 & 6.22 & 0.11 \\
\hline & & \pm & \pm & \pm & \pm & \pm & \pm & \pm & \pm & \pm & \pm & \pm & \pm & \pm & \pm & \pm & \pm & \pm & \pm \\
\hline & & 0.55 & 0.03 & 0.23 & 0.57 & 0.10 & 0.02 & 0.44 & 0.03 & 0.23 & 0.58 & 0.28 & 0.00 & 0.32 & 0.38 & 3.61 & 1.15 & 0.06 & 0.03 \\
\hline & & $\mathrm{a}$ & a & $\mathrm{a}$ & a & d & d & $\mathrm{b}$ & a & $\mathrm{a}$ & bc & a & a & $\mathrm{b}$ & $\mathrm{a}$ & a & $\mathrm{bc}$ & a & a \\
\hline \multirow{16}{*}{ Experimental } & \multirow{4}{*}{ Mint } & 9.10 & 1.49 & 11.36 & 11.23 & 1.65 & 0.30 & 5.85 & 1.94 & 12.90 & 10.69 & 1.28 & 0.07 & 9.47 & 1.26 & 15.82 & 19.47 & 5.11 & 0.24 \\
\hline & & \pm & \pm & \pm & \pm & \pm & \pm & \pm & \pm & \pm & \pm & \pm & \pm & \pm & \pm & \pm & \pm & \pm & \pm \\
\hline & & 0.83 & 0.28 & 0.69 & 2.07 & 0.23 & 0.07 & 0.75 & 0.36 & 0.72 & 1.60 & 0.13 & 0.03 & 1.71 & 0.24 & 2.10 & 5.40 & 1.38 & 0.08 \\
\hline & & c & b & $\mathrm{c}$ & b & $\mathrm{a}$ & b & a & a & b & a & a & $\mathrm{c}$ & a & a & b & a & a & $\mathrm{c}$ \\
\hline & \multirow{4}{*}{ Basil } & 8.53 & 1.46 & 11.15 & 10.78 & 1.91 & 0.27 & 6.15 & 2.31 & 13.42 & 11.39 & 1.51 & 0.11 & 11.22 & 1.57 & 16.47 & 21.31 & 6.10 & 0.35 \\
\hline & & \pm & \pm & \pm & \pm & \pm & \pm & \pm & \pm & \pm & \pm & \pm & \pm & \pm & \pm & \pm & \pm & \pm & \pm \\
\hline & & 0.93 & 0.61 & 0.76 & 1.70 & 0.35 & 0.05 & 1.21 & 0.98 & 0.84 & 1.40 & 0.16 & 0.03 & 2.27 & 0.46 & 2.35 & 2.43 & 0.77 & 0.04 \\
\hline & & $\mathrm{ab}$ & $\mathrm{b}$ & $\mathrm{bc}$ & $a b$ & $\mathrm{~b}$ & $\mathrm{a}$ & $\mathrm{c}$ & $\mathrm{b}$ & $\mathrm{b}$ & $a b$ & a & $\mathrm{e}$ & c & $\mathrm{b}$ & $\mathrm{b}$ & $\mathrm{ab}$ & $\mathrm{a}$ & $\mathrm{e}$ \\
\hline & \multirow{4}{*}{ Marigold } & 8.84 & 1.46 & 11.03 & 11.52 & 2.03 & 0.29 & 6.36 & 2.15 & 13.28 & 10.00 & 1.49 & 0.06 & 12.31 & 1.56 & 16.24 & 19.54 & 6.04 & 0.22 \\
\hline & & \pm & \pm & \pm & \pm & \pm & \pm & \pm & \pm & \pm & \pm & \pm & \pm & \pm & \pm & \pm & \pm & \pm & \pm \\
\hline & & 0.91 & 0.22 & 1.41 & 1.54 & 0.22 & 0.04 & 1.05 & 0.29 & 1.02 & 1.11 & 0.24 & 0.02 & 3.81 & 0.45 & 2.72 & 3.16 & 1.18 & 0.07 \\
\hline & & $\mathrm{bc}$ & $\mathrm{b}$ & $\mathrm{b}$ & $\mathrm{b}$ & $\mathrm{c}$ & $\mathrm{b}$ & $\mathrm{d}$ & $\mathrm{b}$ & $\mathrm{b}$ & $\mathrm{a}$ & $\mathrm{a}$ & $\mathrm{b}$ & $\mathrm{d}$ & $b$ & $\mathrm{~b}$ & $\mathrm{a}$ & $\mathrm{a}$ & $\mathrm{b}$ \\
\hline & \multirow{4}{*}{ Zinnia } & 8.42 & 1.29 & 10.16 & 11.10 & 1.81 & 0.33 & 6.14 & 1.91 & 12.68 & 10.28 & 1.55 & 0.10 & 11.00 & 1.54 & 17.73 & 24.28 & 6.19 & 0.30 \\
\hline & & \pm & \pm & \pm & \pm & \pm & \pm & \pm & \pm & \pm & \pm & \pm & \pm & \pm & \pm & \pm & \pm & \pm & \pm \\
\hline & & 1.28 & 0.50 & 0.96 & 1.62 & 0.29 & 0.12 & 1.03 & 0.96 & 0.94 & 0.78 & 0.28 & 0.05 & 1.55 & 0.55 & 3.21 & 5.00 & 1.70 & 0.13 \\
\hline & & $a b$ & $\mathrm{a}$ & $\mathrm{a}$ & $a b$ & $\mathrm{~b}$ & $\mathrm{c}$ & $\mathrm{c}$ & $\mathrm{b}$ & $\mathrm{c}$ & $\mathrm{c}$ & $\mathrm{a}$ & $\mathrm{d}$ & $\mathrm{c}$ & $\mathrm{b}$ & $\mathrm{c}$ & $\mathrm{c}$ & $\mathrm{a}$ & d \\
\hline & $\mathrm{F}$ & \multicolumn{18}{|c|}{72.111} \\
\hline \multicolumn{2}{|c|}{ Significant } & \multicolumn{18}{|c|}{$.000^{* * *}$} \\
\hline
\end{tabular}


The contents of inorganic components in mixed cultivation by planting ratio were mostly significantly high except magnesium and sodium in roots and stems and calcium and magnesium in leaves (Table 11). As for the difference in inorganic components among individuals by the planting ratio of $30 \%, 50 \%$, and $70 \%$, Wilks' lambda was .000, F-value was 99.609 , and p-value was .000, showing a statistically significant difference, proving that companion planting applying the planting ratio was effective in increasing the contents of inorganic components in the plant body of cherry tomatoes. The posttest results showed that roots showed a difference in all experimental plots from the control plot in magnesium and sodium, and stems showed a difference from the control plot in nitrogen, phosphorus, and sodium. Leaves showed similar contents of calcium and magnesium with the control plot, while the rest showed a difference.

To test the interaction effect, we examined the F-distribution of Wilks' lambda and found that there was a difference in the contents of inorganic components between companion plants and planting type, companion plants and planting ratio, and planting type and planting ratio $(p<.001)$.

Table 10. Analysis of the content of inorganic elements in plants by type of planting.

[Unit: $\mathrm{mg} / \mathrm{kg}^{-1}$ ]

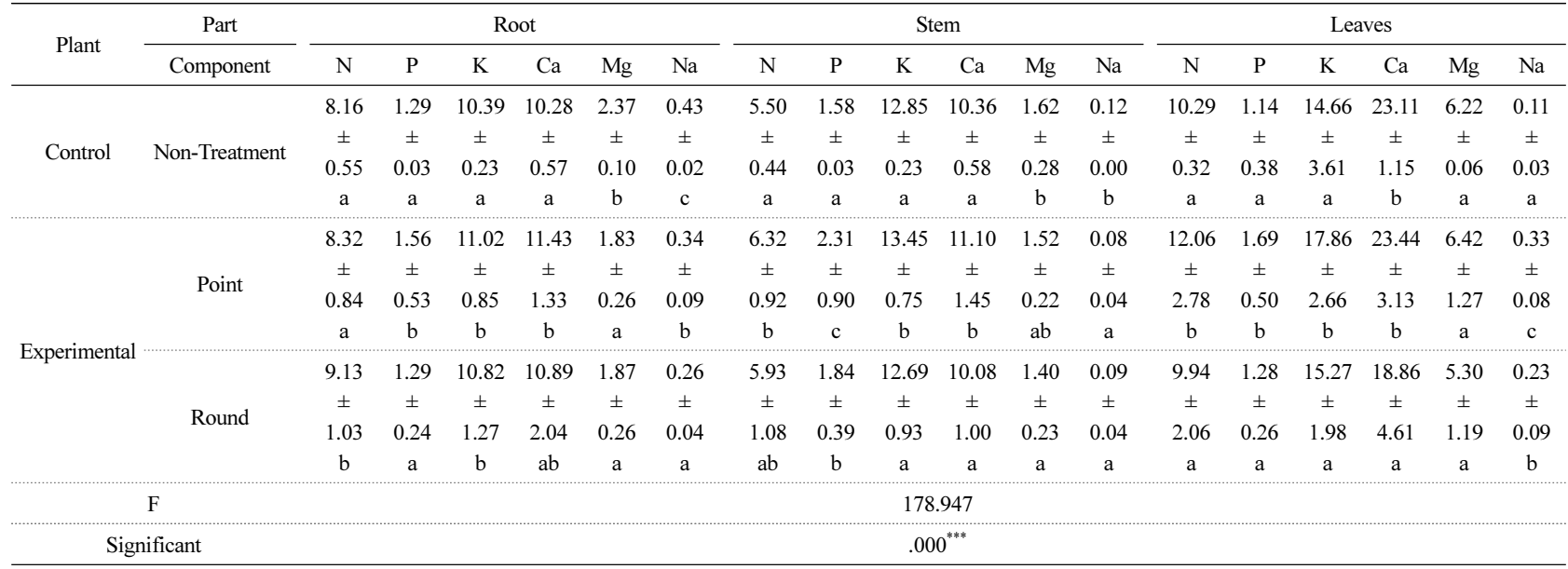

${ }^{* * *} p<.001$ by MANOVA test.

Table 11. Analysis of the content of inorganic elements in plants by treatment ratio.

[Unit: $\left.\mathrm{mg} / \mathrm{kg}^{-1}\right]$

\begin{tabular}{|c|c|c|c|c|c|c|c|c|c|c|c|c|c|c|c|c|c|c|c|}
\hline \multirow{2}{*}{ Plant } & \multirow{2}{*}{$\begin{array}{c}\text { Part } \\
\text { Component }\end{array}$} & \multicolumn{6}{|c|}{ Root } & \multicolumn{6}{|c|}{ Stem } & \multicolumn{6}{|c|}{ Leaves } \\
\hline & & $\mathrm{N}$ & $P$ & $\mathrm{~K}$ & $\mathrm{Ca}$ & $\mathrm{Mg}$ & $\mathrm{Na}$ & $\mathrm{N}$ & $P$ & $\mathrm{~K}$ & $\mathrm{Ca}$ & $\mathrm{Mg}$ & $\mathrm{Na}$ & $\mathrm{N}$ & $\mathrm{P}$ & $\mathrm{K}$ & $\mathrm{Ca}$ & $\mathrm{Mg}$ & $\mathrm{Na}$ \\
\hline \multirow{4}{*}{ Control } & \multirow{4}{*}{$0 \%$} & 8.16 & 1.29 & 10.39 & 10.28 & 2.37 & 0.43 & 5.50 & 1.58 & 12.85 & 10.36 & 1.62 & 0.12 & 10.29 & 1.14 & 14.66 & 23.11 & 6.22 & 0.11 \\
\hline & & \pm & \pm & \pm & \pm & \pm & \pm & \pm & \pm & \pm & \pm & \pm & \pm & \pm & \pm & \pm & \pm & \pm & \pm \\
\hline & & 0.55 & 0.03 & 0.20 & 0.57 & 0.10 & 0.02 & 0.44 & 0.03 & 0.23 & 0.58 & 0.28 & 0.00 & 0.32 & 0.38 & 3.61 & 1.15 & 0.06 & 0.03 \\
\hline & & $\mathrm{a}$ & $\mathrm{a}$ & $\mathrm{a}$ & $\mathrm{a}$ & $\mathrm{b}$ & $\mathrm{c}$ & $\mathrm{a}$ & $\mathrm{a}$ & $\mathrm{a}$ & $\mathrm{a}$ & $b$ & $\mathrm{c}$ & $\mathrm{a}$ & $\mathrm{a}$ & $\mathrm{a}$ & b & $\mathrm{a}$ & $\mathrm{a}$ \\
\hline \multirow{12}{*}{ Experimental } & \multirow{4}{*}{$30 \%$} & 8.99 & 1.72 & 10.89 & 10.64 & 1.82 & 0.27 & 6.06 & 2.57 & 13.18 & 10.33 & 1.39 & 0.08 & 11.26 & 1.74 & 15.88 & 20.82 & 5.83 & 0.26 \\
\hline & & \pm & \pm & \pm & \pm & \pm & \pm & \pm & \pm & \pm & \pm & \pm & \pm & \pm & \pm & \pm & \pm & \pm & \pm \\
\hline & & 1.17 & 0.54 & 1.09 & 1.87 & 0.34 & 0.05 & 0.79 & 0.80 & 0.44 & 1.86 & 0.21 & 0.03 & 2.90 & 0.57 & 2.12 & 5.13 & 1.01 & 0.06 \\
\hline & & $\mathrm{c}$ & b & $\mathrm{b}$ & $\mathrm{a}$ & $\mathrm{a}$ & $\mathrm{a}$ & b & $\mathrm{c}$ & $\mathrm{b}$ & $\mathrm{a}$ & $\mathrm{a}$ & $\mathrm{a}$ & b & $\mathrm{c}$ & b & $\mathrm{a}$ & $\mathrm{a}$ & $\mathrm{b}$ \\
\hline & \multirow{4}{*}{$50 \%$} & 8.76 & 1.28 & 10.61 & 11.01 & 1.84 & 0.32 & 6.10 & 1.85 & 12.93 & 10.81 & 1.50 & 0.10 & 10.41 & 1.25 & 16.37 & 21.51 & 5.85 & 0.26 \\
\hline & & \pm & \pm & \pm & \pm & \pm & \pm & \pm & \pm & \pm & \pm & \pm & \pm & \pm & \pm & \pm & \pm & \pm & \pm \\
\hline & & 0.78 & 0.29 & 0.93 & 1.23 & 0.31 & 0.08 & 0.79 & 0.67 & 1.09 & 1.09 & 0.27 & 0.05 & 2.00 & 0.26 & 3.23 & 3.79 & 1.16 & 0.11 \\
\hline & & $\mathrm{bc}$ & $\mathrm{a}$ & $\mathrm{ab}$ & $a b$ & a & b & b & b & $a b$ & $\mathrm{a}$ & $a b$ & b & $\mathrm{a}$ & $\mathrm{a}$ & $b c$ & $a b$ & $\mathrm{a}$ & b \\
\hline & \multirow{4}{*}{$70 \%$} & 8.41 & 1.27 & 11.26 & 11.83 & 1.89 & 0.31 & 6.22 & 1.81 & 13.09 & 10.63 & 1.49 & 0.08 & 11.33 & 1.46 & 17.45 & 21.11 & 5.90 & 0.32 \\
\hline & & \pm & \pm & \pm & \pm & \pm & \pm & \pm & \pm & \pm & \pm & \pm & \pm & \pm & \pm & \pm & \pm & \pm & \pm \\
\hline & & 1.02 & 0.26 & 1.15 & 1.85 & 0.28 & 0.09 & 1.22 & 0.41 & 1.09 & 0.88 & 0.19 & 0.03 & 2.95 & 0.31 & 2.39 & 4.76 & 1.80 & 0.10 \\
\hline & & $a b$ & $\mathrm{a}$ & $\mathrm{c}$ & b & $\mathrm{a}$ & b & b & b & $\mathrm{ab}$ & $\mathrm{a}$ & $a b$ & a & b & b & $\mathrm{c}$ & $a b$ & $\mathrm{a}$ & $\mathrm{c}$ \\
\hline \multicolumn{2}{|c|}{ F } & \multicolumn{18}{|c|}{99.609} \\
\hline \multicolumn{2}{|c|}{ Significant } & \multicolumn{18}{|c|}{$.000^{* * *}$} \\
\hline
\end{tabular}


As a result of testing the effect among individual factors, Sig. of $\mathrm{F}=.000<.001$, and thus there was an interaction effect among companion plants, planting ratio, and planting type in the contents of inorganic components in the plant body (Table 12).

Irrigation, another factor that affects absorption of inorganic components, was equally treated with drip irrigation, but the moisture demand varied among planted companion plants and thus there was some difference in soil moisture content. Soil moisture content by irrigation is expected to affect absorption of inorganic compounds and thus will be added to future experiments.

\section{Change in sugar content and vitamin $\mathrm{C}$ content of cherry tomatoes}

\section{Change in sugar content}

Sugar content is a factor determining quality, and eating quality varies greatly depending on sugar content. Sugar content increases in a short time as the fruit enters the color stages, and it increases gradually as the fruit matures. Sugar content (fructose, glucose) increases as harvest time is delayed, and the standard sugar content in the full ripe period of cherry tomatoes is $5.8^{\circ} \mathrm{Bx}$ (RDA, 2008). The results of the experiment were as follows: MR7 $8.1^{\circ} \mathrm{Bx}, \mathrm{MP} 7$ \& ZP7 \& ZR7 $7.9^{\circ} \mathrm{Bx}$, TP7 $7.8^{\circ} \mathrm{Bx}$. The lowest sugar content was TR5 $7.0^{\circ} \mathrm{Bx}$, which was generally $1.2-2.3^{\circ} \mathrm{Bx}$ higher compared to conventional culture. This result was similar to the study by Kim et al. (2013) revealing that fruit sugar content increases along with the increasing nitrogen concentration of soil. The control plot showed the sugar content of $7.8^{\circ} \mathrm{Bx}$, which was $2^{\circ} \mathrm{Bx}$ higher than the standard sugar content, and experimental plots other than MR7 / MP7 / ZP7 / ZR7 showed lower sugar content than the control plot (Fig. 3). As a result of verifying the difference among groups through the posttest using Duncan's test, there was no statistical difference. This is similar to the result by Chang et al. (1998) claiming that high manure application increases fruit sugar content. On the other hand, Ehret and Ho (1986) argued that increasing electrical conductivity (EC) of the nutrient solution by mixing $\mathrm{KNO}_{3}$ and $\mathrm{Ca}\left(\mathrm{NO}_{3}\right)_{2}$ compared to $\mathrm{NaCI}$ is more effective in increasing sugar content of cherry tomatoes, which will be

Table 12. Mutual relation of individual factors on this study.

\begin{tabular}{cccc}
\hline Factor & Value & F & Significant \\
\hline Companion plant * Planting type & .000 & 61.293 & $.000^{* * *}$ \\
Companion plant * Planting ratio & .000 & 27.977 & $.000^{* * *}$ \\
Planting type * Planting ratio & .000 & 93.253 & $.000^{* * *}$ \\
Companion plant * Planting type * Planting ratio & .000 & 35.770 & $.000^{* * *}$ \\
\hline
\end{tabular}
${ }^{* * *} p<.001$ by MANOVA test.

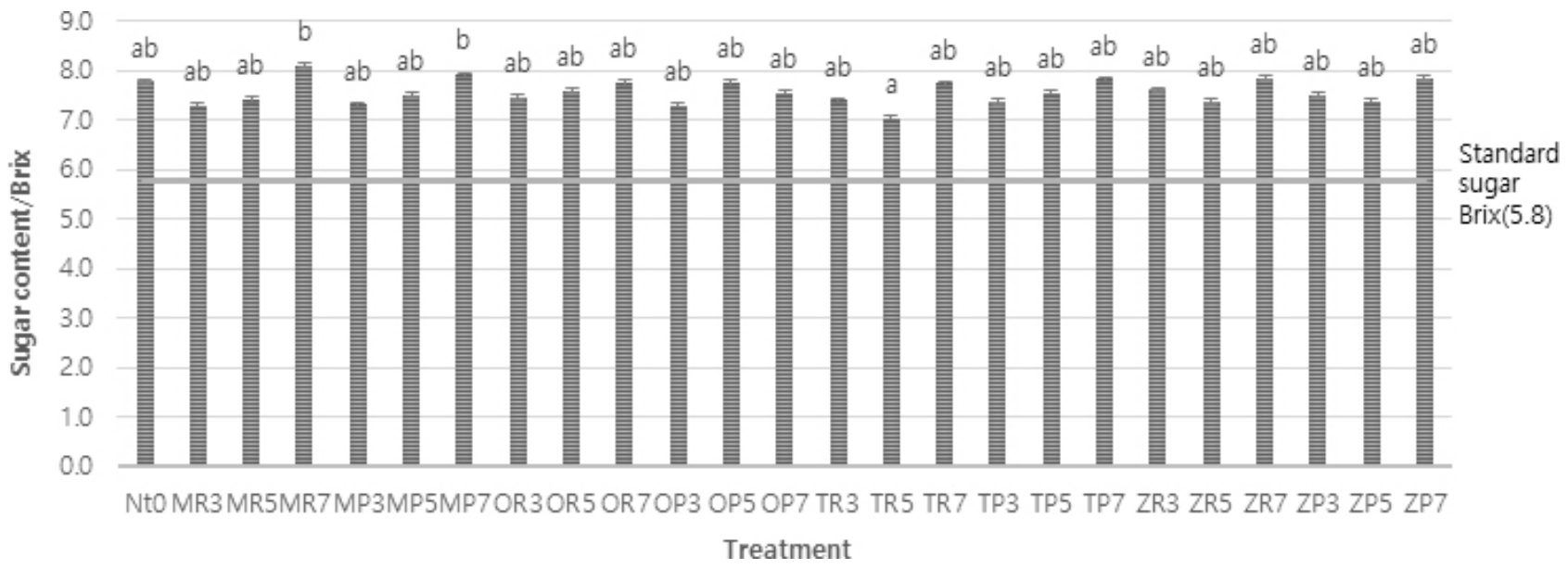

Fig. 3. Sugar content analysis result of cherry tomato. Standard sugar Brix was $5.8^{\circ} \mathrm{Bx}$. 
studied further.

\section{Change in vitamin $\mathbf{C}$ content}

Vitamin $\mathrm{C}$ is known to participate in many biological responses in the human body (Hwang et al., 2014). As a result of analyzing vitamin $\mathrm{C}$ content of fruits existing in two forms such as dehydro-ascorbic acid (DHA) absorbed by facilitated diffusion and ascorbic acid (AA) absorbed by active sodium-dependent transport, the content was highest in the order of MR5 $44.77 \mathrm{mg}>$ TR3 $43.69 \mathrm{mg}$ > TP3 $40.67 \mathrm{mg}>$ OP5 $40.59 \mathrm{mg}>$ TP5 $40.38 \mathrm{mg}$, which was $14.11-18.50 \mathrm{mg}$ higher per $100 \mathrm{~g}$ compared to the control plot at $26.27 \mathrm{mg}$. This was much higher than the standard by Lee (2020) that the adequate vitamin C content of cherry tomatoes is $15.59 \mathrm{mg}$, and also higher in all experimental plots than the full ripe period at $24.0 \mathrm{mg}$ according to the Ministry of Food and Drug Safety (Table 13).

Fruits of cherry tomatoes with mixed cultivation of companion plants generally had high vitamin $\mathrm{C}$ content (Table 14). However, the results of one-way ANOVA showed that F-value was 1.155 and p-value 0.336 , showing no statistically significant difference in testing for individual effects, and thus companion planting did not have an interaction effect with vitamin C content (Table 14).

By planting type, as a result of testing individual effects with vitamin $\mathrm{C}$ content, $\mathrm{F}$-value was 1.64 and $\mathrm{p}$-value 0.206 , showing no interaction effect at the significance level of $p>.05$ with planting type and vitamin $\mathrm{C}$ content (Table 15).

By planting ratio of companion plants, as a result of testing the effects with vitamin $\mathrm{C}$ content, F-value was 0.84 and $p$-value 0.438 , showing no interaction effect with planting ratio and vitamin $\mathrm{C}$ content (Table 16).

Testing the effects among three individual factors in vitamin $\mathrm{C}$ content showed that there was a significant difference between companion plants and planting type, and companion plants and planting ratio $(p<.05)$, but none between planting type and planting ratio $(p>.05)$. However, the effect among three factors was Sig. of $\mathrm{F}=$ $.003<.001$, and thus vitamin $\mathrm{C}$ content had an interaction effect with companion plants, planting ratio, and planting type (Table 17).
Table 13. Results of cherry tomato vitamin $\mathrm{C}$ analysis.

\begin{tabular}{cc}
\hline Treatment $^{2}$ & Vitamin C content $(\mathrm{mg} / 100 \mathrm{~g})$ \\
\hline Nt0 & $26.27 \pm 0.42$ \\
MR3 & $35.83 \pm 4.12$ \\
MR5 & $44.77 \pm 6.96$ \\
MR7 & $39.12 \pm 1.75$ \\
MP3 & $31.52 \pm 1.81$ \\
MP5 & $38.34 \pm 0.72$ \\
MP7 & $39.43 \pm 1.92$ \\
OR3 & $40.04 \pm 0.49$ \\
OR5 & $36.50 \pm 0.10$ \\
OR7 & $39.07 \pm 0.67$ \\
OP3 & $35.34 \pm 0.71$ \\
OP5 & $40.59 \pm 0.54$ \\
OP7 & $36.27 \pm 0.20$ \\
TR3 & $43.69 \pm 1.41$ \\
TR5 & $35.88 \pm 0.49$ \\
TR7 & $36.62 \pm 0.77$ \\
TP3 & $40.67 \pm 1.17$ \\
TP5 & $40.38 \pm 0.29$ \\
TP7 & $31.78 \pm 7.86$ \\
ZR3 & $37.70 \pm 1.28$ \\
ZR5 & $33.20 \pm 0.43$ \\
ZR7 & $35.58 \pm 2.53$ \\
ZP3 & $39.88 \pm 1.07$ \\
ZP5 & $34.61 \pm 1.36$ \\
ZP7 & $40.14 \pm 0.99$ \\
Significant & $.001 * * *$ \\
\hline & \\
\hline &
\end{tabular}

${ }^{\mathrm{z}}$ Treatment were derived from Table 1 .

$* * * p<.001$ by ANOVA test.

\section{Physicochemical change of soil}

Soil includes many natural inorganic nutrients that are absorbed by plants to use for growth and then returned back to soil at the end of life. However, farmland soil where crops are grown has inorganic nutrients contained in the harvests removed from soil through cultivation repeated every year, and thus certain nutrients are likely to be insufficient. Thus, we identified the state of inorganic nutrients in soil changed after harvest to determine whether farmland soil can be reused or not (Table 18). Soil pH is an important element that determines solubility of inorganic nutrients, and cherry tomatoes like subacidity of 
Table 14. Results of cherry tomato vitamin $\mathrm{C}$ analysis by companion plants.

[Unit: mg/100g]

\begin{tabular}{|c|c|c|c|c|c|c|c|}
\hline \multirow{2}{*}{ Factor } & Control & \multicolumn{4}{|c|}{ Experimental } & \multirow{2}{*}{$\mathrm{F}$} & \multirow{2}{*}{ Significant } \\
\hline & Non-treatment & Mint & Basil & Marigold & Zinnia & & \\
\hline Vitamin C & $26.27 \pm 0.42$ & $38.17 \pm 5.08$ & $37.9 \pm 2.11$ & $36.85 \pm 2.93$ & $38.17 \pm 4.86$ & 1.155 & $0.336^{\mathrm{NS}}$ \\
\hline
\end{tabular}

${ }^{\mathrm{NS}}$ Non-significant by ANOVA test.

Table 15. Results of cherry tomato vitamin $\mathrm{C}$ analysis by type of planting.

[Unit: mg/100g]

\begin{tabular}{cccccccc}
\hline \multirow{2}{*}{ Factor } & Control & & \multicolumn{2}{c}{ Experimental } & \multirow{2}{*}{ F } & Significant \\
\cline { 2 - 3 } & Non-treatment & & Point & Round & & \\
\hline Vitamin C & $26.27 \pm 0.42$ & & $38.17 \pm 3.93$ & $37.41 \pm 3.91$ & & 1.641 & $0.206^{\text {NS }}$ \\
\hline
\end{tabular}

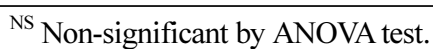

Table 16. Results of cherry tomato vitamin $\mathrm{C}$ analysis by treatment ratios.

[Unit : mg/100g]

\begin{tabular}{|c|c|c|c|c|c|c|}
\hline \multirow{2}{*}{ Factor } & \multirow{2}{*}{$\begin{array}{c}\text { Control } \\
0 \%\end{array}$} & \multicolumn{3}{|c|}{ Experimental } & \multirow{2}{*}{$\mathrm{F}$} & \multirow{2}{*}{ Significan } \\
\hline & & $30 \%$ & $50 \%$ & $70 \%$ & & \\
\hline Vitamin C & $26.27 \pm 0.42$ & $38.08 \pm 3.94$ & $38.03 \pm 4.18$ & $37.25 \pm 3.70$ & 0.839 & $0.438^{\mathrm{NS}}$ \\
\hline
\end{tabular}

${ }^{\mathrm{NS}}$ Non-significant by ANOVA test.

Table 17. Mutual relation of individual factors on this study.

\begin{tabular}{ccccc}
\hline Factor & $\mathrm{R}^{2}$ & Adjusted R & F & Significant \\
\hline Companion plant * Planting type & & & 4.750 & $.005^{* *}$ \\
Companion plant * Planting ratio & & $.000^{* * *}$ & 12.337 & $.076^{\mathrm{NS}}$ \\
Planting type * Planting ratio & .788 & .686 & 2.710 & $.003^{* *}$ \\
Companion plant * Planting type * Planting ratio & & & 3.940 & \\
\hline
\end{tabular}

NS, ${ }^{* *},{ }^{* * *}$ Non-significant $p<.01, p<.001$ by ANOVA test.

pH 6.0-6.5 (Yun et al., 2000). Soil in the cultivation plot had $\mathrm{pH}$ in the range of 5.5-9.0, and it was weakly alkaline $(\mathrm{pH} 7.7)$ in all experimental plots except garden zinnia. This is because, as reported by Park and Kim (1998), there is a great amount of anion absorption such as nitrate nitrogen when there is active vegetative growth, and cation absorption such as $\mathrm{K}^{+}$increases in reproductive growth and thus hydrogen ions $\left(\mathrm{H}^{+}\right)$are released from the roots. Electrical conductivity (EC) was $0.1 \mathrm{ds} / \mathrm{m}$ and thus adequate for the threshold (below 0.2). Moreover, as inorganic components of the plant body decreased, the concentrations of potassium, calcium, and sodium in the soil increased, which caused antagonism among cations in the absorption process at the roots, thereby increasing relative absorption amount of magnesium and reducing the amount remaining in soil. Nonetheless, soil chemical properties after harvesting cherry tomatoes showed high acidity in upland soil (RDA, 2020), and low contents of phosphoric acid, exchangeable potassium, calcium, and magnesium. Therefore, it is necessary to plow $60-70 \mathrm{~cm}$ deep to secure pore void, adequately adjust the amount of irrigation considering the smooth drainage due to deep tillage, and implement management practices to minimize use of nitrogen fertilizers.

\section{Conclusion}

This study was conducted to identify various factors of companion planting affecting the growth of cherry toma- 
Table 18. Characteristic of soil on cultivation plot after harvest.

\begin{tabular}{|c|c|c|c|c|c|c|c|c|c|}
\hline \multirow{2}{*}{ Treatment $t^{y}$} & \multirow{2}{*}{$\frac{\mathrm{pH}}{(1: 5)}$} & \multirow{2}{*}{$\frac{\mathrm{EC}}{(\mathrm{dS} / \mathrm{m})}$} & \multirow{2}{*}{$\frac{\text { avaliable } \mathrm{P}_{2} \mathrm{O}_{5}}{(\mathrm{mg} / \mathrm{kg})}$} & \multicolumn{4}{|c|}{ Exchangeable. Cation $(\mathrm{cmol}+/ \mathrm{kg})$} & \multirow{2}{*}{$\frac{\mathrm{OM}}{(\mathrm{g} / \mathrm{kg})}$} & \multirow{2}{*}{$\begin{array}{c}\mathrm{N} \\
(\%)\end{array}$} \\
\hline & & & & $\mathrm{K}$ & $\mathrm{Ca}$ & $\mathrm{Mg}$ & $\mathrm{Na}$ & & \\
\hline $\mathrm{Nt} 0$ & 8.4 & 0.14 & 59.22 & 0.40 & 4.09 & 2.18 & 0.13 & 11 & 0.05 \\
\hline MR3 & 8.6 & 0.07 & 67.65 & 0.27 & 3.99 & 1.93 & 0.14 & 3.4 & 0.03 \\
\hline MR5 & 8.4 & 0.07 & 51.53 & 0.27 & 4.11 & 2.07 & 0.15 & 3.2 & 0.02 \\
\hline MR7 & 8.4 & 0.09 & 47.45 & 0.27 & 3.97 & 2.11 & 0.16 & 3.3 & 0.02 \\
\hline MP3 & 8.4 & 0.07 & 57.57 & 0.30 & 3.76 & 2.07 & 0.12 & 4.5 & 0.03 \\
\hline MP5 & 8.4 & 0.06 & 53.86 & 0.29 & 4.42 & 2.14 & 0.14 & 7.1 & 0.03 \\
\hline MP7 & 8.6 & 0.11 & 55.33 & 0.30 & 4.00 & 2.07 & 0.15 & 7.9 & 0.03 \\
\hline OR3 & 8.8 & 0.12 & 114.64 & 0.35 & 4.95 & 2.00 & 0.14 & 9.2 & 0.04 \\
\hline OR5 & 9.0 & 0.14 & 123.80 & 0.31 & 5.39 & 2.08 & 0.14 & 12.5 & 0.04 \\
\hline OR7 & 6.3 & 0.18 & 219.47 & 0.33 & 7.36 & 1.92 & 0.13 & 13.7 & 0.05 \\
\hline $\mathrm{OP} 3$ & 8.5 & 0.09 & 78.50 & 0.29 & 4.79 & 2.09 & 0.14 & 7.2 & 0.03 \\
\hline OP5 & 8.8 & 0.07 & 58.30 & 0.43 & 5.64 & 3.00 & 0.20 & 7.9 & 0.03 \\
\hline OP7 & 8.7 & 0.06 & 63.98 & 0.41 & 6.13 & 2.97 & 0.21 & 9.1 & 0.04 \\
\hline TR3 & 8.7 & 0.04 & 46.81 & 0.34 & 4.07 & 2.00 & 0.18 & 6.2 & 0.02 \\
\hline TR5 & 9.0 & 0.04 & 51.30 & 0.33 & 4.62 & 2.06 & 0.17 & 8.7 & 0.02 \\
\hline TR7 & 5.7 & 0.03 & 61.60 & 0.31 & 4.57 & 2.13 & 0.14 & 9.8 & 0.02 \\
\hline TP3 & 8.0 & 0.04 & 49.69 & 0.28 & 3.88 & 2.03 & 0.15 & 4.2 & 0.01 \\
\hline TP5 & 8.0 & 0.04 & 73.65 & 0.28 & 4.00 & 2.04 & 0.14 & 6.2 & 0.04 \\
\hline TP7 & 8.2 & 0.04 & 59.68 & 0.32 & 4.20 & 2.18 & 0.14 & 8.2 & 0.03 \\
\hline ZR3 & 6.0 & 0.03 & 54.78 & 0.32 & 4.09 & 2.17 & 0.14 & 5.5 & 0.02 \\
\hline ZR5 & 5.9 & 0.03 & 67.05 & 0.36 & 4.06 & 2.19 & 0.12 & 3.8 & 0.02 \\
\hline ZR7 & 5.8 & 0.03 & 72.50 & 0.36 & 4.66 & 2.35 & 0.13 & 6.1 & 0.03 \\
\hline ZP3 & 5.5 & 0.03 & 39.62 & 0.27 & 3.39 & 2.00 & 0.15 & 2.4 & 0.01 \\
\hline ZP5 & 6.0 & 0.03 & 61.69 & 0.48 & 6.38 & 3.64 & 0.20 & 7.4 & 0.04 \\
\hline $\mathrm{ZP7}$ & 5.6 & 0.03 & 65.36 & 0.35 & 4.65 & 2.31 & 0.16 & 9.6 & 0.03 \\
\hline SD & 7.7 & 0.1 & 70.20 & 0.3 & 4.6 & 2.2 & 0.2 & 7.12 & 0.03 \\
\hline
\end{tabular}

${ }^{\mathrm{y}}$ Treatment were derived from Table 1.

toes, which will contribute to promoting urban agriculture by improving socioeconomic satisfaction of urban residents with gardening activities through high yield, quality improvement, and adequate fertilization. We created 76 for 5 days starting April 10, 2020 and planted cherry tomatoes accompanied by spearmint, basil, marigold, and garden zinnia in the point type and round type at the ratios of $0 \%$, $30 \%, 50 \%$, and $70 \%$, and conducted an experiment in triplicate. The results are as follows.

First, the growth of cherry tomatoes increased more significantly in companion planting than monoculture. Companion planting did not affect growth, but there was a statistically significant difference in planting type and planting ratio. As a result of testing the effect among three individual factors, there was a significant difference between companion plants and planting type, and planting type and planting ratio, but no interaction effect between companion plants and planting ratio, and among companion plants, planting type, and planting ratio.

Second, as a result of analyzing the contents of inorganic components by harvesting the aerial parts of cherry tomatoes 70 days after sowing, there was a significant difference at the level of $0.1 \%$. We tested the effect among individual factors for each part of the plant body and discovered that 
there was a statistically significant difference in all of companion plants, planting type, and planting ratio. Wilks' statistics to test the interaction effect showed a difference in the contents of inorganic components between companion plants and planting type, companion plants and planting ratio, and planting type and planting ratio $(p<.001)$. As a result of testing the effect among individual factors, Sig. of $F=0.000<0.001$ and thus there was an interaction effect among companion plants, planting ratio, and planting type in the contents of inorganic components.

Third, sugar content was higher in both the experimental plots and control plot than the standard sugar content at $5.8^{\circ} \mathrm{Bx}$, and like the growth survey, the point type at the $70 \%$ ratio of spearmint and marigold showed high sugar content. The lowest sugar content was found in the round type at the $50 \%$ ratio of marigold at $7.0^{\circ} \mathrm{Bx}$, which was $1.2-2.3^{\circ} \mathrm{Bx}$ higher than standard sugar content.

Fourth, vitamin $\mathrm{C}$ content was higher in all experimental plots than the standard amount of $24.0 \mathrm{mg} / 100 \mathrm{~g}$ at full ripe period and was statistically significant. However, the result of one-way ANOVA showed that companion plants, planting type, and planting ratio did not have a significant difference with vitamin $\mathrm{C}$ content.

Fifth, the soil $\mathrm{pH}$ of the cultivation plot was within the range of 5.5-9.0, weakly alkaline $(\mathrm{pH} 7.7)$ in all experimental plots except garden zinnia, and showing low contents of phosphoric acid, exchangeable potassium, calcium, and magnesium. Therefore, it is necessary to plow $60-70 \mathrm{~cm}$ deep to secure pore void, adequately adjust the amount of irrigation considering the smooth drainage due to deep tillage, and implement management practices to minimize use of nitrogen fertilizers.

This study was conducted to identify various factors such as the growth of cherry tomatoes, contents of inorganic components in the plant body, sugar and vitamin $\mathrm{C}$ content of fruits, and soil analysis according to companion plants, planting type, and planting ratio to determine the effect of companion planting on the growth and quality of cherry tomatoes, establish the foundation for growth to ensure high quality and yield to meet the needs of urban residents, and provide management convenience through succession cropping. However, the limitation of this study is that it failed to separately examine management practices and irri- gation time during the growth of cherry tomatoes. The effect on main crops may vary depending on the root development and growth speed until transplant after sowing, and thus we will further study sugar content by measuring the change in growth every phase and analyzing content in each phase of maturity and full ripeness of fruits.

\section{References}

Bever J.D. 1994. Feedback between plants and their soil communities in an old field community. Ecology 75:1965-1977. https://doi.org/10.2307/1941601

Bomford, M.K. 2009. Do tomatoes love basil but hate brussels sprouts Competition and land-use efficiency of popularly recommended and discouraged crop mixtures in biointensive agriculture systems. J. Sustain. Agric. 33(4): 396-417. https://doi.org/10.1080/10440040902835001

Borowy, A. 2012. Growth and yield of stake tomato under no-tillage cultivation using hairy vetch as a living mulch. Acta Sci. Polonorum-Hortorum 11(2):229-252.

Chae, S.M. 2020. Impacts of water volume per irrigation event and irrigation frequency on photosynthesis and performance of plant and fruit growth for Tomato substrate hydroponics. Master's thesis, Korea National Open University, Seoul, Korea.

Chae, Y., I.K. Hong, S.M. Lee, Y.B. Jung, K.S. Han, Y.A. Jang, and S.H. Youk. 2019. Effects of mixed cultivation of companion plant in urban garden on the pest development and growth of cabbages. Hortic. Sci. Technol. 37(Suppl I ):75-76. https://www.dbpia.co.kr/p df/pdfView.do?nodeId=NODE08740071

Chang, C.L, X.P. Fu, X.G. Zhou, M.Y. Guo, and F.Z. Wu. 2017. Effects of seven different companion plants on cucumber productivity, soil chemical characteristics and Pseudomonas community. J. Integrat. Agri. 16(10): 2206-2214. https://doi.org/10.1016/S2095-3119(17)61698-8

Chang, K.W, S.H. Cho, and I.B. Lee. 1998. Study on the improvement of soil for high efficient and sustainable agriculture-I. Effect of repeated application of chicken and pig manure composts on tomato growth and soil physico-chemical properties. Agri. Chem. Biotech. 41(6): 451-456.

Doran J.W. and Zeiss M.R. 2000. Soil health and sustain- 
ability: Managing the biotic component of soil quality. Appl. Soil Ecol. 15(1):3-11. https://doi.org/10.1016/S09 29-1393(00)00067-6

Ehret, D.L. and L.C. Ho. 1986. The effects of salinity on dry matter partitioning and fruit growth in tomatoes grown in nutrient film culture. J. Hortic. Sci. 61(3):361-367. https://doi.org/10.1080/14620316.1986.11515714

Gómez-Rodríguez, O., E. Zavaleta-Mejía, V.A. GonzálezHernández, M. Livera-Munoz, and E. Cárdenas-Soriano. 2003. Allelopathy and microclimatic modification of intercropping with marigold on tomato early blight disease development. Field Crops Res. 83(1):27-34. https://doi.o rg/10.1016/S0378-4290(03)00053-4

Hanan, J.J. 1998. Greenhouses:Advanced technology for protected horticulture, Prentice Hall, Up Perlite Saddle River, NJ, USA.

Held. D.W, P. Gonsiska, and D.A. Potter. 2003. Evaluating Companion Planting and Non-host Masking Odors for Protecting Roses from the Japanese Beetle (Coleoptera: Scarabaeidae). J. Econ. Entomol. 96(1): 81-87. https://doi. org/10.1603/0022-0493-96.1.81

Hong, I.K. H.K. Yun, Y.B. Jung, and S.M. Lee. 2021. A survey on perception of companion plants for eco-friendly urban agricultural among urban residents. J. People Plants Environ. 24(1):17-27. https://doi.org/10.11628/ksppe.20 21.24.1.17

Hwang, I.G, J.Y. Byun, K.M. Kim, M.N. Chung, and S.M. Yoo. 2014. Vitamin C quantification of Korean sweet potatoes by cultivar and cooking method. J. Korean Soc. Food Sci. Nutr. 43(6):955-961. https://doi.org/10.3746/j kfn.2014.43.6.955

Jedrszczyk, E and M. Poniedziaek. 2007. The impact ofthe living mulch on plant growth and selected features of sweet corn yield. Folia Hortic. 19(1):3-13.

Kim, E.Y., B.J. Park, and M.M. Oh. 2013. Availability of slurry composting and biofiltration for cultivation of cherry tomato. Prot. Hortic. Plant Fact. 22(4):385-391. https://doi.org/10.12791/KSBEC.2013.22.4.385

Lee, K.S. 2005. Effects of fertigation on quality and yield of cherry tomato(Lycopersicum esculentum Mill.). Master's thesis, Korea University, Seoul, Korea.

Lee, S.H. 2020. Quality characteristics of cherry tomatoes by different drying temperatures and blanching times. Master's thesis. Chungbuk National University, Cheongju,
Korea.

Lenucci, M.S., D. Cadinu, M. Taurino, G. Piro, and G. Dalessandro. 2006. Antioxidant composition in cherry and high-pigment tomato chltivars. J. Agric. Food Chem. 54(7):2606-2613. https://doi.org/10.1021/jf052920c

Lindsay, W.L. 1979. Chemical equilibra in soil.s. New York, USA:John Wiley \& Sons, Inc.

Liu, T., Z. Cheng., H. Meng, I. Ahmad, and H. Zhao. 2014. Growth, yield and quality of spring tomato and physicochemical properties of medium in a tomato/garlic intercropping system under plastic tunnel organic medium cultivation. Sci. Hortic. 170(7):159-168. http://dx.doi.org/ 10.1016/j.scienta.2014.02.039

Lu, Y.C., K.B. Watkins, J.R. Teasdale, A.A. Abdul-Baki. 2000. Cover crops in sustainable food production. Food Rev. Int. 16(2):121-157. https://doi.org/10.1081/FRI-10 0100285

Marschner, H. 1995. mineral nutrition of higher plants. $2^{\mathrm{ND}}$ ed. San Diego, USA:Academic Press Inc.

Mengel, K and E.A. Kirkby. 1987. Principles of plant nutrition. $4^{\text {th }}$ ed. Intl. Bern, Switzerland:Potash Inst.

Ministry of food and drug safety(MFDS). 2000. Food safety. Retrieved from http://www.foodsafetykorea.go.kr/foodc ode/01_03.jsp?idx=317

Moon, S.R. 2011. Attraction and repellent effects of spot clothing Wax cicada, Lycorma delicatula against plant essential oils. Department of agicultural biology graduate school, Master's thesis, Chungbuk National University, Cheongju, South Korea. https://dcollection.chungbuk.ac. kr/public_resource/pdf/000000021520_2021080217163 7.pdf

Moon, W and D.J. Yoo. 2013. Physiology of cultivated plants. Seoul, Korea: Seoul National University of Broadcasting and Communications.

National Institute of Agricultural Science and Technology (NIAST). 2000. Methods of soil chemical analysis. Suwon, Korea:RDA

Park, K.W. and Y.S. Kim. 1998. Hydroponics in horticulture, $1^{\text {st }}$ ed. Seoul, Korea:Academy Books.

Papadopopoulos, I. 1986. Nitrogen fertigation of greenhouse-grown cucumber, Plant and Soil 93:87-93. https://doi.org/10.1007/BF02377148

Putten W, C.V. Dijk, and B.A.M. Peters. 1993. Plant-specific 
soil-borne diseases contribute to succession in foredune vegetation. Nature, 362:53-56. https://doi.org/10.1038/3 $62053 \mathrm{a} 0$

Rural Development Administration(RDA). 2012. $5^{\text {th }}$ Edition Agricultural science and technology:Research survey analysis standards. Suwon, Korea:RDA.

Rural Development Administration(RDA). 2008. Field professional training for horticultural crops for farmers: Cherry tomato. Suwon, Korea:RDA.

Rural Development Administration(RDA). 2005. Agricultural management information:Requirements and business cases for improving the received prices of fruits and vegetables. Suwon, Korea:RDA.

Rural Development Administration(RDA). 2020. Crop soil management technology. Jeonju, Jeollabuk-do Korea: RDA.

Shin, Y.S., H.N. Yoo, S.H. Jeong, Y.H. Yun, and J.H. Joo. 2014. Environmentally friendly urban agriculture using public plants in roof greening. Kor. Environ. Sci.
Society Conference 23:741-743.

Tringovska, I, Yankova, V, Markova, D, Mihov, M. 2015. Effect of companion plants on tomato greenhouse production. Sci. Hortic. 186:31-37. https://doi.org/10.10 16/j.scienta.2015.02.016

Valentin V., G. Antoine, P. Elise, M. Safia, M. David, and V.M. Muriel. 2017. Can legume companion plants control weeds without decreasing crop yield? A meta-analysis. Field Crops Res. 204:158-168. https://doi.org/10.1016/j. fcr.2017.01.010

Vernon, R.S, G.V.H. Willem, C. Markus, and J. Tolman. 2016. Companion planting attract-and-kill method for wireworm management in potatoes. J. Pest Sci. 89: 375-389. https://doi.org/10.1007/s10340-015-0707-6.

Yun, H.K., X.R. Li, I.S. Kim, and K.C. Yoo. 2000. Physicochemical properties in the sand-based media. Inst. of Agr. Sci. Kangwon Nat'l Univ. J. Agri. Sci. 11:12-19. 